\title{
Prediction Model Kualitas Aplikasi Sistem Informasi Pembayaran Tiket (E-Ticket) Yang Dipengaruhi Oleh Budaya Organisasi Serta Dampaknya Terhadap Kualitas Informasi Akuntansi Untuk Pengambilan Keputusan
}

\author{
Lilis Puspitawati ${ }^{1}$, Novi Indriani Siti Nurshalihat ${ }^{2}$ \\ Program Studi Akuntansi, Fakultas Ekonomi dan Bisnis, Universitas Komputer Indonesia, Bandung, Indonesia \\ Email: lilis.puspitawati@email.unikom.ac.id
}

\begin{abstract}
The success of the Accounting Information System in producing quality Accounting information. Accounting Information Systems play an important role in an organization for the achievement of organizational goals that are effective and efficient. The existence of an accounting information system in an organization is nothing but to be able to produce useful information for its users in the decision making process. To be able to produce quality accounting information, we need a reliable accounting information system in processing data and transactions so that the information generated can be useful in decision making. The method used in this research is descriptive and verification methods. Observation Unit conducted at PT. Kereta Api Indonesia (Persero) Bandung City with its analysis unit are employees in the accounting sub-division 20 people and the system 20 people. The statistical test used is the calculation of Structural Equation Modeling (SEM) with a variance-based analysis of Partial Least Square (PLS) and hypothesis testing using the help of the Smart PLS 3.0 application. Based on the research conducted it can be seen that (1) Organizational culture is significantly influences the quality of accounting information system (2) the quality of accounting information system significantly influences the quality of accounting information.
\end{abstract}

Keywords: Organizational Culture, Quality of Accounting Information System, and Quality of Accounting Information

\begin{abstract}
ABSTRAK
Sistem Informasi Akuntansi berperan penting dalam suatu organisasi untuk pencapaian tujuan organisasi yang efektif dan efisien. Keberadaan sistem informasi akuntansi dalam suatu organisasi tidak lain adalah untuk dapat menghasilkan informasi yang bermanfaat bagi penggunanya dalam proses pengambilan keputusan. Untuk dapat menghasilkan informasi akuntansi yang berkualitas, diperlukan suatu sistem informasi akuntansi yang andal dalam mengolah data dan transaksi sehingga informasi yang dihasilkan dapat berguna dalam pengambilan keputusan. Budaya Organisasi merupakan salah satu faktor yang mendukung kesuksesan Sistem Informasi Akuntansi dalam menghasilkan informasi yang berkualitas. Metode yang digunakan dalam penelitian ini adalah metode deskriptif dan verifikatif. Unit Pengamatan dilakukan di PT. Kereta Api Indonesia (Persero) Kota Bandung dengan unit analisisnya adalah karyawan pada sub bagian akuntansi 20 orang dan sistem 20 orang. Uji statistik yang digunakan adalah perhitungan Structural Equation Modeling (SEM) dengan analisis varians berbasis Partial Least Square (PLS) dan pengujian hipotesis menggunakan bantuan aplikasi Smart PLS 3.0. Berdasarkan penelitian yang dilakukan dapat diketahui bahwa (1) Budaya organisasi berpengaruh signifikan terhadap kualitas sistem informasi akuntansi (2) kualitas sistem informasi akuntansi berpengaruh signifikan terhadap kualitas informasi akuntansi.
\end{abstract}

Kata Kunci: Budaya Organisasi, Kualitas Sistem Informasi Akuntansi, dan Kualitas Informasi Akuntansi

\section{Pendahuluan}

Informasi merupakan hasil pengolahan data yang memilki arti serta bermanfaat bagi berbagai penggunanya[1]. Informasi memiliki peran penting disegala aspek kehidupan umat manusia baik secara individu maupun secara organisasi. Informasi membantu organisasi mencapai titik optimalnya; efektivitas dari informasi memudahkan mengidentifikasi pesaing dan menganalisa keuntungan kompetitor lain[2]. Informasi merupakan suatu hal yang penting bagi kehidupan manusia untuk menambah wawasan dan pengetahuan bagi individu dan organisasi. Dengan 
informasi seseorang yang awalnya tidak tahu menjadi tahu, awalnya tidak mengerti menjadi mengerti[3].

Salah satu kegunaan utama dari informasi adalah sebagai dasar pengambilan keputusan bagi berbagai penggunanya. Namun, tidak semua informasi dapat bermanfaat bagi yang menggunakannya. Individu dan organisasi membutuhkan informasi yang berkualitas sebagai untuk dijadikan dasar pengambilan keputusan[1] Agar dapat dikatakan berkualitas informasi harus memiliki karakterisitik/ciri yang merupakan ciri khas melekat dari kualitas informasi tersebut[4]. Adapun menurut[5], ciri utama dari kualitas informasi harus memiliki sifat relevansi dan realibilitas yang merupakan dua kualitas primer yang membuat informasi akuntansi berguna untuk pengambilan keputusan.

Beberapa ahli berpendapat, informasi akuntansi yang berkualitas tergantung dari kualitas sistem informasi akuntansi yang digunakannya. Seiring dengan kemajuan teknologi, kualitas informasi akuntasi berkembang seiring dengan meningkatnya penggunaan aplikasi sistem informasi pada berbagai industry dengan tujuan untuk meningkatkan kepuasan pengguna agar dapat dengan mudah melakukan akses untuk pengambilan keputusan[6].

Sistem informasi akuntansi merupakan sebuah sistem yang memproses data dan transaksi guna menghasilkan informasi yang bermanfaat untuk merencanakan, mengendalikan, dan mengoperasikan bisnis[3]. Sedangkan menurut[7], Sistem informasi akuntansi adalah kumpulan sumber daya yang dirancang untuk mengubah data keuangan menjadi suatu informasi. Manfaat Sistem informasi akuntansi dapat dievaluasi melalui pengaruh pada peningkatan proses pengambilan keputusan, kualitas pada informasi akuntansi, evaluasi kinerja, internal control, dan transaksi perusahaan[8].

Perilaku pengguna sangat mendukung kesuksesan sistem informasi akuntansi. Kesuksesan penerapan sistem informasi akuntansi sangat berdampak pada dihasilkannya kualitas informasi akuntansi untuk memenuhi ciri khas keandalan sehingga dapat memuaskan berbagai pengguna dan mengoptimalkan kinerja perusahaan. Pencapaian kinerja juga berkaitan dengan tugas, kebutuhan, dan kemampuan individu dalam organisasi, karena sistem informasi dalam teknologi[9].

Adapun masalah yang dialami saat ini, masih terdapat kualitas aplikasi Sistem informasi akuntansi yang rendah karena sering mengalami error (tidak handal) yang terjadi pada PT. Kereta Api Indonesia dalam penerapan sistem informasi Rail Ticketing System yang masih belum optimal, berbagai user berpendapat bahwa masalah utama dalam sistem informasi tersebut adalah jaringan, seringnya jaringan tersebut tidak stabil sehingga memperlambat karyawan untuk menginput data. Hal ini tentu saja akan mempengaruhi aktifitas kerja karyawan sehingga tidak optimal[10].

Kondisi tersebut masih terjadi hingga saat ini, beberapa pengguna masih mengalami kesulitan dalam mengakses sistem pembayaran tiket (e-ticket) pada PT KAI Indonesia. Kepala Humas Daerah Operasi (Daop) I Jakarta Sukendar Mulya (2020) meminta masyarakat maklum, bila saat ini kesulitan untuk mengakses website KAI untuk memesan tiket via online. Menurutnya, situs resmi KAI error lantaran sangat banyak masyarakat yang tengah mengakses website KAI secara bersamaan. Bermasalahnya aplikasi $e$-ticket tersebut karena

Sistem informasi yang berkualitas dipengaruhi oleh berbagai macam faktor salah satunya adalah melalui faktor budaya organisasi[11]. Budaya organisasi memainkan peran penting dalam implementasi sistem informasi[12]. Budaya organisasi merupakan social control system bagi komponen organisasi yang bertujuan untuk mengendalikan perilaku sesuai dengan perilaku yang diharapkan agar tujuan organisasi dapat tercapai[13]. 
Budaya organisasi memiliki ciri terstandardisasi (baku) dan tidak fleksible karena harus diterapkan secara general dalam suatu organisasi. kondisi tersebut menjadi suatu kelemahan budaya organisasi karena budaya organisasi dapat menjadi hambatan bagi perubahan dalam perusahaan, manakala nilai-nilai yang dimiliki bersama tidak sejalan dengan nilai-nilai yang dapat meningkatkan efektivitas organisasi[14].

Hal ini terbukti dari adanya permasalahan yang dialami oleh PT. Kereta Api Indonesia (KAI), seperti yang dinyatakan oleh junior manager PT. KAI bahwa, mengubah kultur dari product oriented menjadi costumer oriented awalnya hambatan bagi perusahaan. Awalnya, Kereta Api Indonesia (KAI) memiliki kultur product oriented. Tak peduli pelayanan jelek kalu mau naik silahkan. Corporate culture inilah menjadi penghambat yang harus diubah kalau tidak PT. KAI tidak akan mampu bersaing dengan jenis moda transportasi yang lainnya. Customer oriented culture digunakan untuk merespon perubahan yang terjadi di lingkungan eksternal, yaitu faktor persaingan dari moda transportasi lain dan harapan sosial dimana saat ini masyarakat sebagai konsumen memiliki ekspetasi tinggi terhadap pelayanan angkutan kereta api yang lebih baik dan cepat.

Penelitian ini bertujuan untuk mengembangkan model prediksi untuk kesuksesan penerapan aplikasi sistem informasi pembayaran ticket melalui faktor budaya organisasi serta dampaknya terhadap kualitas informasi untuk pengambilan keputuasan. Selain itu peneliti juga ingin mengetahui Seberapa besar pengaruh budaya organisasi terhadap kesuksesan penerapan sistem pembayaran tiket (e-ticket) serta seberapa besar pengaruh kesuksesan penerapan sistem informasi pembayaran Tiket (e-ticket) terhadap dihasilkanya informasi berkualiatas bagi pengambilan keputusan user.

\section{Kerangka Teoritis dan Pengembangan Hipotesis}

\section{Budaya Organisasi}

Robbins \& Judge [14] mendefinisikan budaya organisasi sebagai "a system of shared meaning held by members that distinguishes the organization from other organizations" atau dengan kata lain budaya organisasi merupakan sebuah sistem untuk menstransfer norma/aturan/perilaku yang disepakati Bersama oleh seluruh anggota organisasi yang menjadi ciri/pembeda organisasi dengan organisasi yang lainnya.

Terdapat 4 komponen dasar yang membentuk Budaya Organisasi menurut[15], yaitu:

a. Anggapan Dasar (Basic Assumptions)

b. Nilai-Nilai (Values)

c. Norma (Norms)

d. Artifacts

\section{Kualitas Sistem informasi Pembayaran Tiket (e-tiket)}

Supriyati mendefinisikan sistem adalah suatu kumpulan komponen yang saling terhubung untuk mencapai satu tujuan tertentu[16]. Sistem informasi pembayaran merupakan salah satu komponen/sub-sistem dari sistem informasi akuntansi. Sistem informasi Akuntansi merupakan kumpulan dari sub sistem atau komponen yang berinterakasi secara harmonis dalam melakukan aktivitas pengolahan data keuangan/akuntansi yang bertujuan untuk menghasilkan informasi akuntansi keuangan melalui media laporan keuangan yang dapat digunakan berbagai user dalam 
melakukan pengambilan keputusan strategis. Sistem informasi pembayaran tiket (e-ticket) merupakan sub sitem siklus pengolahan transaksi (SPT) penerimaan atau penjualan[4].

Selanjutnya, [17]menjelaskan bahwa, kesuksesan penerapan Aplikasi Sistem informasi harus memiliki unsur indikator sebagai berikut:
a. Efisiensi (Efficiency)
b. Kemudahan Akses (Accessibility)
c. Integrasi (Integration)

\section{Kualitas Informasi Akuntansi}

Menurut [1] informasi akuntansi yang berkualitas mengandung makna informasi akuntansi yang berguna bagi berbagai penggunanya untuk pengambilan keputusan dan memiliki ciri keakurasian, kecepatan dan kesesuaian dengan kebutuhan manajemen dan kelengkapan dari informasi yang dihasilkan.

Selanjutnya menurut[18], menjelaskan bahwa ciri dari informasi yang berkualitas adalah:

a. Akurat, Informasi harus menceeminkan keadaan yang sebenar-benarnya

b. Tepat Waktu, Informasi harus tersedia atau ada pada saat informasi diperlukan

c. Relevan, Informasi yang diberikan harus sesuai dengan yang dibutuhkan

d. Lengkap, Informasi harus diberikan secara lengkap

\section{Pengaruh Budaya Organisasi Terhadap kesuksesan penerapan Sistem Informasi Akuntansi}

Salah satu faktor yang menentukan keberhasilan Sistem Informasi Akuntansi dalam menghasilkan informasi yang berkualitas adalah budaya organisasi. Sistem Informasi Akuntansi berperan penting dalam suatu organisasi demi tercapainya tujuan organisasi yang efektif dan efisien, maka Sistem Informasi Akuntansi harus di desain dengan mencerminkan nilai-nilai dari budaya organisasi karena budaya organisasi merupakan salah satu komponen penting yang dapat mempengaruhi desain suatu Sistem Informasi Akuntansi[19].

Selanjutnya Laudon dan Laudon[6], menjelaskan bahwa "Organizational culture is a component in the organization has a strong influence on information systems". Dari pernyataan tersebut dapat diartikan Budaya organisasi merupakan komponen dalam organisasi yang memiliki pengaruh kuat terhadap sistem informasi. selanjutnya dalam penelitian [20] menyatakan bahwa hasil penelitian dari penelitiannya adalah budaya organisasi berimplikasi signifikan terhadap sistem informasi akuntansi.

5. Kesuksesan penerapan Sistem Informasi Akuntansi Terhadap Kualitas Informasi Akuntansi.

Menurut [19] Sistem informasi akuntansi yang dapat diandalkan adalah sistem yang mempunyai pengendalian memadai sehingga informasi akuntansi yang dihasilkan oleh sistem tersebut dapat diandalkan untuk digunakan dalam pengambilan keputusan.

Konsep tersebut telah di uji oleh beberapa peneliti terdahulu. Penelitian [21] membuktikan bahwa terdapat pengaruh sistem informasi akuntansi terhadap kualitas informasi akuntansi telah diteliti bahwa efektifitas sistem informasi akuntansi membuktikan pengaruh pada kualitas informasi akuntansi. 
Selanjutnya, penelitian [8] di perusahaan bursa efek Teheran, hasil penelitian ini menguji efektivitas sistem informasi akuntansi dalam lima tingkatan yang berbeda: pengambilan keputusan yang lebih baik oleh manajer, sistem kontrol internal yang lebih efektif, peningkatan kualitas laporan keuangan, peningkatan ukuran kinerja, memfasilitasi proses transaksi keuangan. Temuan penelitian menunjukkan bahwa penerapan sistem infomasi akuntansi dapat mengarah pada pengambilan keputusan yang lebih baik oleh manajer.

\section{Hipotesis Penelitian}

Mengacu pada Fenomena, teori-teori dan hasil penelitian terdahulu maka peneliti mengajukan hipotesis penelitian sebagai berikut:

$\mathrm{H}_{1}$ : Budaya organisasi berpengaruh signifikan terhadap kualitas sistem informasi akuntansi

$\mathrm{H}_{2}$ : Kualitas sistem informasi akuntansi berpengaruh signifikan terhadap kualitas informasi akuntansi

\section{Metode Penelitian}

Menurut [22] pengertian metode penelitian adalah metode penelitian merupakan cara ilmiah untuk mendapatkan data yang valid dengan tujuan dapat ditemukan, dibuktikan dan dikembangkan suatu pengetahuan sehingga gilirannya dapat digunakan untuk memahami, memecahkan, dan mengidentifikasi masalah. Penelitian ini menggunakan metode deskriftif dan verifikatif. Tujuan metode verifikatif adalah untuk mendapatkan bukti empiris terkait dengan pengaruh antar variabel yang diteliti melalui pengujian hipotesis yang telah dirumuskan sebelumnya, serta untuk menghasilkan model prediksi yang diharapkan. Sedangkan digunakannya metode desktriftif adalah untuk dapat mengetahui secara detail gambaran kondisi dari masing-masing variable yang diteliti. Variabel yang digunakan dalam penelitian ini terdiri dari Variabel bebas $(\mathrm{X})$, variable terikat $(\mathrm{Z})$ dan variable intervening (Y). Budaya Organisasi dioperasionalisasikan sebagai variable $\mathrm{X}$, efektifitas penerapan aplikasi Sistem Informasi pembayaran tiket sebagai variabel Y, serta Kualitas Informasi Akuntansi sebagai variable Z. Penelitian ini menggunakan sumber data primer, dimana data primer dalam hasil penelitian ini adalah hasil kuesioner yang telah dibagikan kepada reponden. Teknik penggumpulan data dalam penelitian ini adalah dengan cara menyebarkan kuesioner menggunakan email, google form, atau melakukan wawancara langsung di tempat penelitian.

\section{Populasi, Sampel dan Teknik penarikan sampel penelitian}

Menurut [22] populasi adalah wilayah atau generalisasi yang terdiri atas obyek/subyek yang mempunyai kualitas. Populasi dalam penelitian ini adalah pegawai/karyawan pada unit/bagian/department yang terkait dengan penggunaan aplikasi sistem pembayaran tiket (e-ticket) pada PT. Kereta Api Indonesia (Persero) Kota Bandung dengan jumlah ukuran populasi sebanyak 40 pegawai.

Sehubungan dalam penelitian ini menggunakan SEM-PLS, maka dibutuhkan kriteria sampel minimal. Peneliti menggunakan kriteria sampel minimal Rule of tumb (Hair,et.al, 2014), dimana ukuran sampel minimal yang disyaratkan adalah sebanyak 40 responden, sehingga ukuran sampel dalam penelitian ini menggunakan Teknik sampling jenuh yang artinya seluruh anggota populasi menjadi sampel penelitian Sampel merupakan jumlah dari populasi [22]. Sampel pada penelitian ini adalah 40 responden pada 2 sub bagian yaitu sub bagian Akuntansi dan Sistem pada PT. Kereta Api Indonesia (Persero) Kota Bandung. 


\section{Analisis Data Penelitian.}

Dalam penelitian ini dilakukan 2 (dua) analisis data yaitu analisis deskriptif dan analisis verifikatif. Tahapan analisis data tersebut, selanjutnya dijelaskan dalam penjelasan berikut ini.

a. Alat yang digunakan untuk melakukan analisis deskriftif adalah statistik desktiptif. [23] menyatakan bahwa statistik deskriptif adalah statistik yang digunakan untuk menganalisa data dengan cara mendeskripsikan atau menggambarkan data yang telah terkumpul sebagaimana adanya tanpa bermaksud membuat kesimpulan yang berlaku untuk umum atau generalisasi.

b. Alat analisis yang tepat untuk melakukan analisis verifikatif adalah Structural Equation ModellingPartial Least Square (SEM-PLS). Menurut [24] Penggunaan Structural Equation Modeling (SEM) memungkinkan peneliti untuk menyatukan beberapa variabel yang tidak teramati yang diukur secara tidaklangsung oleh indikatornya serta dapat digunakan untuk menghitung kesalahan pengukuran pada variabel yang teramati.

\section{Hasil dan Pembahasan}

\section{Hasil Uji Validitas dan Reliabilitas Instrument penelitian}

Suatu alat ukur dinyatakan valid atau sah apabila memiliki koefisien validitas $\geq 0,30$. Hasil uji validitas disajikan pada tabel 1 . Selanjutnya, suatu alat ukur dinyatakan reliabel apabila memiliki nilai koefisien $\geq 0,70$. Hasil reliabilitas disajikan pada tabel 4.2

\section{Hasil Analis Deskriptif}

a. Analisis Deskriptif Budaya Organisasi.

Hasil perhitungan persentase total skor variabel Budaya Organisasi adalah sebesar 572 (71,50\%) berada di antara interval 68,01\% - 84\%. Dengan demikian dapat katakan bahwa budaya organisasi pada PT. Kereta Api Indonesia (Persero) Kota Bandung telah diterapkan dengan baik, dalam arti responden telah mamahami asumsi dasar, Nilai-Nilai, Norma-norma, dan contoh teladan kinerja yang diterapkan dalam suatu organisasi.

\section{b. Analisis Deskriptif Kualitas aplikasi Sistem Informasi pembayaran tiket (e-ticket)}

Hasil perhitungan persentase total skor dari variabel Kualitas Sistem Informasi pembayaran tiket sebesar 397 (66,17\%) berada di antara interval 52,01\%-68\%. Dengan demikian dapat diartikan bahwa variabel Sistem Informasi pembayaran tiket berada dalam kategori cukup, hal ini menunjukan bahwa masih terdapat permasalahan pada kualitas sistem informasi pembayaran tiket, khususnya pada indikator efesiensi dan kemudahan akses, kondisi tersebut membuktikan fenomena yang telah dinyatakan sebelumnya dalam latar belakang penelitian.

\section{c. Analisis Deskriptif Kualitas Informasi Akuntansi}

Hasil perhitungan persentase total skor dari variabel Kualitas Informasi Akuntansi sebesar 568 (71\%) berada di antara interval 68,01\% - 84,00\%. Dengan demikian dapat diartikan bahwa variabel Kualitas Informasi Akuntansi dalam kategori baik. 
@ is The Best: Accounting Information Systems and Information Technology Business Enterprise

ISSN: 2252-9853 (Print) | ISSN: 2656-808X (Online)

\section{Hasil Analis Verifikatif.}

a. Hasil Pengujian Validitas dan Reliabilitas Kuesioner Penelitian.

Hasil Pengujian validitas instrument penelitian dapat dilihat melalui tabel 1, berikut ini:

Tabel 1 Rekapitulasi Hasil Pengujian Validitas \& Reliablitias Instrumen

\begin{tabular}{|c|c|c|c|c|c|c|}
\hline Variabel & $\begin{array}{l}\text { Koefisien } \\
\text { Validitas }\end{array}$ & $\begin{array}{l}\text { Titik } \\
\text { Kritis }\end{array}$ & KET & $\begin{array}{l}\text { Koefisien } \\
\text { Relibilitas }\end{array}$ & $\begin{array}{c}\text { Titik } \\
\text { Kritis }\end{array}$ & KET \\
\hline \multirow{4}{*}{ Budaya Organisasi (X) } & 0,694 & \multirow{11}{*}{0,3} & \multirow{11}{*}{ Valid } & \multirow{4}{*}{0,833} & \multirow{11}{*}{0.7} & \multirow{11}{*}{ Relibel } \\
\hline & 0,715 & & & & & \\
\hline & 0,851 & & & & & \\
\hline & 0,841 & & & & & \\
\hline \multirow{3}{*}{$\begin{array}{l}\text { Kualitas Sistem } \\
\text { Informasi Akuntansi } \\
\text { (Y) }\end{array}$} & 0,612 & & & \multirow{3}{*}{0,833} & & \\
\hline & 0,510 & & & & & \\
\hline & 0,730 & & & & & \\
\hline \multirow{4}{*}{$\begin{array}{l}\text { Kualitas Informasi } \\
\text { Akuntansi }(\mathrm{Z})\end{array}$} & 0,822 & & & \multirow{4}{*}{0,833} & & \\
\hline & 0,803 & & & & & \\
\hline & 0,770 & & & & & \\
\hline & 0,815 & & & & & \\
\hline
\end{tabular}

sumber: hasil pengolahan Pls.

Berdasarkan informasi dari tabel 1 tersebut menunjukan bahwa semua pertanyaan yang mewakili variable penelitian dinyatakan valid atau dengan kata lain kuesioner yang diajukan telah tapat mengukur variable yang diteliti dalam penelitian ini. Berdasarkan table tersebut diketahui pula semua pertanyaan kuesioner termasuk dalam kategori reliabel artinya adalah kuesioner konsisten mengukur variabel-variabel yang diteliti.

\section{b. Pengujian Model Pengukuran (Outer Model)}

1) Pengujian Validitas Model Penelitian

a) Convergent Validity. Berhubungan dengan prinsip bahwa indikator dari suatu konstruk seharusnya berkolerasi tinggi, dapat dilihat dari nilai outer loading untuk tiap indikator konstruk, harus lebih dari 0,5-0,6 tergolong cukup, sedangkan jika lebih besar dari 0,7 dikategorikan tinggi[23]. Maka nilai average variance extracted dan communality harus lebih dari 0,5. Hasil uji convergent validity dapat dilihat pada tabel 2 menunjukan bahwa indikator- 
indikator memiliki korelasi tinggi atau memiliki keterikatan yang baik dengan variabel yang diteliti.

Tabel 2. Loading Factor

\begin{tabular}{|c|c|c|c|}
\hline \multicolumn{2}{|c|}{ Variabel Manifes } & Loading Faktor & Keterangan \\
\hline AD & Anggapan Dasar & 0,746 & Valid \\
\hline NN & Nilai-Nilai & 0,863 & Valid \\
\hline N & Norma & 0,913 & Valid \\
\hline AR & Artifact & 0,927 & Valid \\
\hline \multicolumn{2}{|c|}{ Variabel Manifes } & Loading Faktor & Keterangan \\
\hline E & Efesiensi & 0,784 & Valid \\
\hline KA & Kemudahan Akses & 0.784 & Valid \\
\hline I & Integritas & 0.864 & Valid \\
\hline \multicolumn{2}{|c|}{ Variabel Manifes } & Loading Faktor & Keterangan \\
\hline A & Akurat & 0,880 & Valid \\
\hline L & Lengkap & 0,802 & Valid \\
\hline R & Relevan & 0,843 & Valid \\
\hline TW & Tepat Waktu & 0,863 & Valid \\
\hline
\end{tabular}

b) Discriminity Validity. Dapat dilihat dari cross loading factor dengan konstruk dan perbandingan akar $A V E$ dengan korelasi variabel laten. Hasil nilai cross loading factor dapat dilihat pada tabel 3 indikator yang digunakan dalam penelitian ini telah tepat mengukur variabel yang diteliti.

Tabel 3. Cross Loading Factor

\begin{tabular}{|c|c|c|c|}
\hline & $\begin{array}{c}\text { Budaya Organisasi } \\
(\mathrm{X})\end{array}$ & $\begin{array}{c}\text { Kualitas Sistem } \\
\text { Informasi } \\
\text { Akuntansi (Y) }\end{array}$ & $\begin{array}{c}\text { Kualitas Informasi } \\
\text { Akuntansi (Z) }\end{array}$ \\
\hline A & 0,792 & 0,477 & 0,88 \\
\hline
\end{tabular}




\begin{tabular}{|c|c|c|c|}
\hline & $\begin{array}{c}\text { Budaya Organisasi } \\
(\mathrm{X})\end{array}$ & $\begin{array}{c}\text { Kualitas Sistem } \\
\text { Informasi } \\
\text { Akuntansi (Y) }\end{array}$ & $\begin{array}{c}\text { Kualitas Informasi } \\
\text { Akuntansi (Z) }\end{array}$ \\
\hline AD & 0,746 & 0,301 & 0,716 \\
\hline AR & 0,927 & 0,487 & 0,808 \\
\hline E & 0,367 & 0,784 & 0,488 \\
\hline I & 0.533 & 0.864 & 0.602 \\
\hline KA & 0.284 & 0.784 & 0.301 \\
\hline L & 0.834 & 0.519 & 0.802 \\
\hline N & 0,913 & 0,569 & 0,776 \\
\hline NN & 0,863 & 0,333 & 0,685 \\
\hline R & 0,614 & 0,531 & 0,843 \\
\hline TW & 0,687 & 0,52 & 0,863 \\
\hline
\end{tabular}

2) Pengujian Reliabilitas model penelitian

Uji reliabilitas dalam Partial Least Square dapat menggunakan Composite Reliability (CR) yang disajikan pada tabel 4.5, Batasan suatu indikator mempunyai konsistensi internal yang baik adalah nilai CR di atas 0.7[24]. Berdasarkan tabel 4 diketahui bahwa indikator yang digunakan memiliki konsistensi internal yang baik.

Tabel 4.Composite Reliability

\begin{tabular}{|c|c|c|}
\hline Variabel Laten & $\begin{array}{c}\text { Composite } \\
\text { Reliability }\end{array}$ & Alpha Cronbach \\
\hline Budaya Organisasi (X) & 0,922 & 0,888 \\
\hline Kualitas Sistem Informasi Akuntansi (Y) & 0,852 & 0,751 \\
\hline Kualitas Informasi Akuntansi (Z) & 0,910 & 0,869 \\
\hline
\end{tabular}




\section{3) Hasil Uji kecocokan Model (Fit Test Of Combination Model)}

Uji kecocokan seluruh model gabungan (fit test of combination mode) adalah uji kecocokan untuk memvalidasi model secara keseluruhan menggunakan nilai Goodness of Fit $(G o F)$. Berdasarkan hasil uji kecocokan model yang disajikan pada tabel 5 dan 6, menunjukan bahwa model variabel yang digunakan yaitu Kualitas aplikasi sistem informasi pembayaran telah tepat diprediksi oleh variabel budaya pangaruh organisasi serta Kualitas Informasi akuntansi telah tepat diprediksi oleh variabel Kualitas aplikasi sistem informasi pembayaran.

Tabel 5. Hasil Nilai GoF Y

\begin{tabular}{|c|c|c|}
\hline & Communality & R Square \\
\hline Variabel Y & 0.748 & 0.265 \\
\hline Perkalian & \multicolumn{2}{|c|}{0.198} \\
\hline Nilai GoF & \multicolumn{2}{|c|}{0.445} \\
\hline
\end{tabular}

Tabel 6. Hasil Nilai GoF Z

\begin{tabular}{|l|c|c|}
\hline & Communality & R Square \\
\hline Variabel Z & 0.718 & 0.367 \\
\hline Perkalian & \multicolumn{2}{|c|}{0.263} \\
\hline Nilai GoF & \multicolumn{2}{|c|}{0.512} \\
\hline
\end{tabular}

\section{c. Pengujian Model Struktural (Inner Model).}

1) Pengujian Model Struktural

Model structural (Inner Model) dalam penelitian ini disajikan dalam gambar berikut ini:

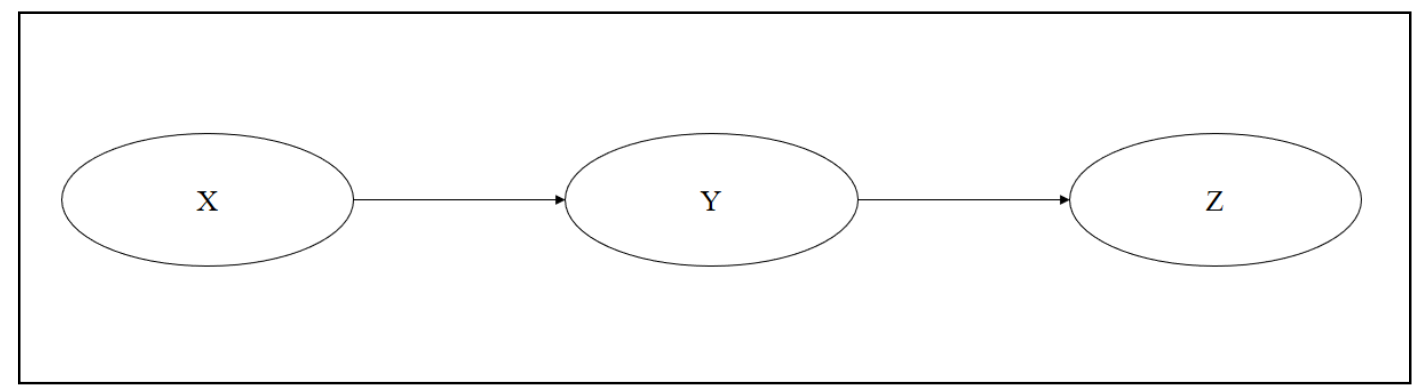

Gambar 1. Model Struktural. 


\section{Keterangan:}

$\mathrm{X} \quad$ : Variabel Budaya Organisasi

Y : Variabel Kualitas Sistem Informasi pembayaran tiket

Z : Variabel Kualitas Informasi Akuntansi

Selanjutnya kombinasi model pengukuran (outer model) dan model struktural (inner model) secara keseluruhan dapat dilihat pada gambar di bawah ini:

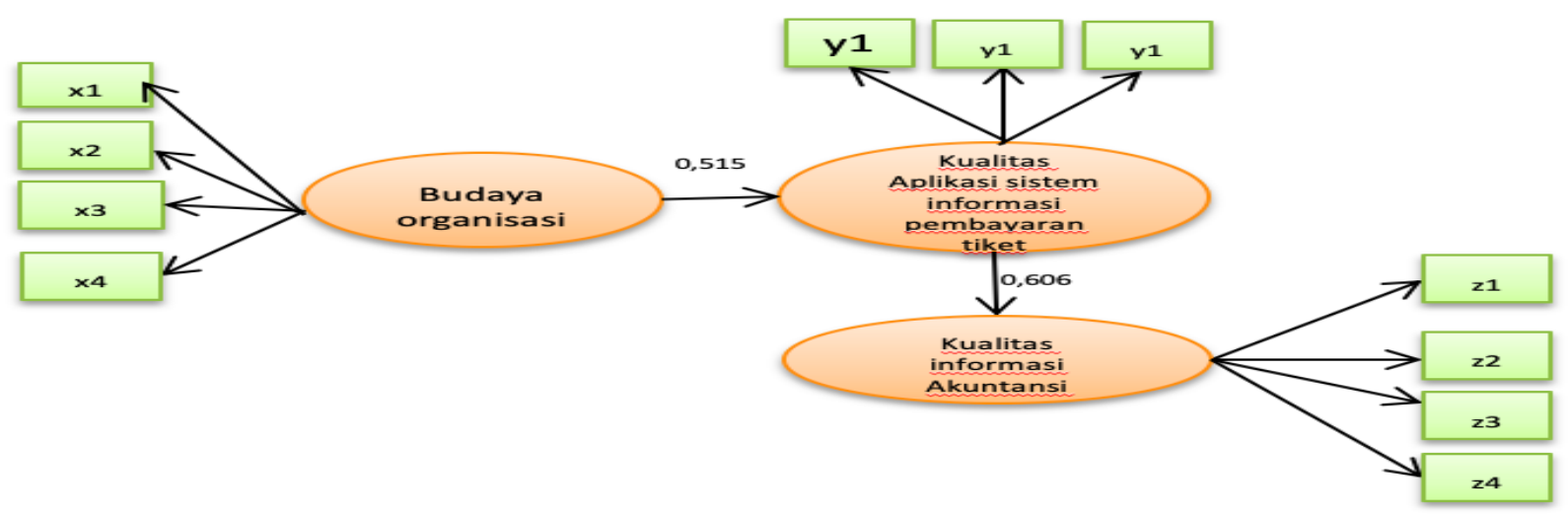

Gambar 2. Model Prediksi Kualitas Informasi yang dipengaruhi oleh Budaya Organisasi yang berdampak pada kualitas informasi akuntansi

\section{Keterangan}

$\mathrm{X}_{1} \quad$ : Asumsi dasar

$\mathrm{X}_{2} \quad$ : nilai-nilai

$\mathrm{X}_{3}$ : norma

$\mathrm{X}_{4} \quad:$ artifact

$\mathrm{Y}_{1}$ : efisiensi

$\mathrm{Y}_{2} \quad$ : kemudahan akses

$\mathrm{Y}_{3} \quad$ : integrase

$Z_{1} \quad$ : Akurat

$\mathrm{Z}_{2} \quad$ : tepat waktu

$\mathrm{Z}_{3}$ : relevan

$\mathrm{Z}_{4} \quad$ : lengkap 
2) Pengujian Hipotesis penelitian.

Untuk melihat apakah pengaruh yang diberikan oleh kedua variabel laten eksogen tersebut signifikan atau tidak, dilakukan pengujian hipotesis. Hipotesis dalam penelitian ini diuji dengan menggunakan nilai koefisien path dan t-values.

Tabel 7. Uji $t$ Budaya Organisasi (X) Terhadap Kualitas Sistem Informasi Akuntansi (Y)

\begin{tabular}{|c|c|c|c|c|c|}
\hline $\begin{array}{c}\text { Latent } \\
\text { Variable }\end{array}$ & Koefisien Jalur & $\mathbf{t}_{\text {statistik }}$ & $\mathbf{t}_{\text {kritis }}$ & Keterangan & Kesimpulan \\
\hline $\mathbf{X}$-> Y & 0,514 & 3,337 & 0,001 & Ho ditolak & Signifikan \\
\hline
\end{tabular}

Tabel 8. Uji $t$ Kualitas Sistem Informasi Akuntansi (Y) Terhadap Kualitas Laporan Keuangan (Z)

\begin{tabular}{|c|c|c|c|c|c|}
\hline $\begin{array}{c}\text { Latent } \\
\text { Variable }\end{array}$ & Koefisien Jalur & $\mathbf{t}_{\text {statistik }}$ & $\mathbf{t}_{\text {kritis }}$ & Keterangan & Kesimpulan \\
\hline $\mathbf{Y ~ - > ~ Z ~}$ & 0,606 & 4.305 & 0,000 & Ho ditolak & Signifikan \\
\hline
\end{tabular}

Hasil pengujian Hipotesisi pada tabel 7 dan 8 menunjukan bahwa kedua hipotesis yang diajukan dalam penelitian dapat diterima, artinya bahwa:

a) Kualitas Aplikasi sistem informasi pembayaran tiket secara signifikan dapat diprediksi oleh perubahan yang terjadi dalam budaya organisasi perusahaan serta

b) Kualitas informasi akuntansi secara signifikan dapat diprediksi oleh perubahan yang terjadi pada kualitas sistem informasi pembayaran tiket (e-tiket)

\section{Pembahasan}

\section{a. Pengaruh Budaya Organisasi Terhadap Kualitas Sistem Informasi Akuntansi}

Berdasarkan hasil penelitian menyatakan bahwa budaya organisasi berpengaruh signifikan terhadap kualitas aplikasi sistem informasi pembayaran tiket (e-ticket) berdasarkan kriteria $t_{\text {hitung }}>$ $t_{\text {tabel }}(3,337>2.02)$. Koefisien jalur bertanda positif yang berarti semakin baik budaya organisasi maka kualitas aplikasi sistem informasi pembayaran tiket (e-ticket) semakin baik. Variabel budaya organisasi berpengaruh terhadap kualitas aplikasi sistem informasi pembayaran tiket (e-ticket) sebesar $26.42 \%$. Hasil ini sesuai dengan pendapat dari [9] dan [6] bahwa sistem informasi akuntansi tidak dapat berdiri sendiri dan dipengaruhi oleh berbagai faktor pendukungnya diantaranya adanya faktor budaya organisasi perusahaan. Karenanya, kualitas aplikasi sistem informasi pembayaran tiket (e-ticket) mempunyai hubungan yang erat dengan operasi fisik dan budaya organisasi perusahaan. Hasil penelitian ini sejalan dengan penelitian yang dilakukan oleh [20] pada tahun 2011 yang menunjukan adanya pengaruh diantara dua variabel yang diteliti 


\section{b. Pengaruh Kualitas Sistem Informasi Akuntansi Terhadap Kualitas Informasi Akuntansi}

Hasil penelitian ini membuktikan kualitas aplikasi sistem informasi pembayaran tiket (e-ticket) berpengaruh sebesar 26,42\% terhadap Kualitas Informasi Akuntansi ( $Z$ ) dengan nilai korelasi sebesar 0,514 yang berarti kualitas aplikasi sistem informasi pembayaran tiket (e-ticket) memberikan pengaruh yang kuat arah positif terhadap Kualitas Informasi Akuntansi pada PT. Kereta Api Indonesia (Persero) Kota Bandung. Arah hubungan positif kualitas aplikasi sistem informasi pembayaran tiket (e-ticket) terhadap Kualitas Informasi Akuntansi menunjukan bahwa Kualitas Sistem Informasi Akuntansi yang semakin baik akan meningkatkan Kualitas Informasi Akuntansi. Hasil penelitian menguatkan peneltian terdahulu yang dilakukan oleh [21][25][26] serta penelitian yang dilakukan oleh [8] bahwa kualitas aplikasi sistem informasi Akuntansi berpengaruh terhadap dihasilkannya informasi akuntansi yang berkualitas yang dibutuhkan oleh berbagai penggunanya sebagai dasar dalam proses pengambilan strategis.

\section{Penutup}

Budaya Organisasi berpengaruh terhadap kualitas aplikasi sistem informasi pembayaran tiket (e-ticket dengan arah positif yang menunjukan hubungan yang searah antara budaya organisasi terhadap kualitas aplikasi sistem informasi pembayaran tiket (e-ticket), dimana semakin meningkat budaya organisai maka kualitas sistem informasi akuntansi akan ikut meningkat. Namun ada beberapa yang menyebabkan variabel budaya organisasi belum maksimal yaitu pada indikator artifact. Sehingga berimbas pada Kualitas Informasi Akuntansi yang kurang maksimal. Oleh karena itu untuk mengoptimalkan organisasi harus melakukan sosialisasi dan publikasi mengenai visi/misi yang telah ditetapkan serta didukung oleh sarana dan prasarana yang memadai. Kualitas aplikasi sistem informasi pembayaran tiket (e-ticket) berpengaruh terhadap Kualitas Informasi Akuntansi, dimana semakin baik kualitas aplikasi sistem informasi pembayaran tiket (e-ticket) akan meningkatkan Kualitas Informasi Akuntansi. Namun dalam penelitian ini masih dijumpai adanya indikator dengan hasil penelitian yang optimal sehingga berdampak pada menurunnya kualitas aplikasi sistem informasi pembayaran tiket (e-ticket) yaitu indikator efesiensi dan kemudahan akses. Kondisi tersebut memang telah tergambar pda fenomena awal yang dijelaskan dalam latar belakang penelitian bahwa adanya masih belum berkualitasnya aplikasi pembayaran tiket pada PT. KAI Indonesia karena Aplikasi masih sering mengalami gangguan dan lambat dalam merespon transksi. Kondisi ini tentunya akan berdampak pada pada Kualitas Informasi Akuntansi. PT. KAI perlu mengkaji kembali terkait fitur dan kemudahan akses dalam aplikasi yang digunakan saat ini. kualitas aplikasi sistem informasi pembayaran tiket (e-ticket) harus bisa terintegrasi dengan sistem informasi lainya yang sekirannya dapat mempercepat proses pengolahan informasi akuntansi secara matang, sehingga informasi tersebut dapat digunakan untuk pengambilan keputusan yang cepat dan efektif. Belum optimal indikator artifact dalam variabel budaya organisasi dapat diperbaiki dengan cara melakukan sosialisasi dan publikasi mengenai visi misi yang telah ditetapkan serta didukung oleh srana dan prasarana yang memadai. Masih adanya permasalahan pada indikator Kemudahan Akses, PT. KAI disarankan perlu meningkatkan hardware, jaringan komunikasi dan server yang digunakan saat ini sehingga kinerja aplikasi dapat meningkat. pada peneliti selanjutnya disarankan untuk dapat mencari populasi yang lebih luas sehingga dapat penelitian dapat terkumpul dengan lebih banyak, serta menambahkan variabel lain yang diprediksi dapat mempengaruhi kualitas sistem informasi akuntansi. 


\section{Daftar Pustaka}

[1] A. Susanto, Sistem Informasi Akuntansi. Bandung: Lingga Jaya, 2013.

[2] Malin, "Efektifitas Sistem Informasi Akuntansi." pp. 20-26, 2004.

[3] Krismiaji, Sistem Informasi Akuntansi. Yogyakarta: UPP AMP YKPN, 2012.

[4] L. Puspitawati and S. D. Anggadini, Sistem Informasi Akuntansi, Edisi Pert. Yogyakarta: Graha Ilmu, 2011.

[5] D. E. Kieso, J. J. Weygandt, and T. D. Warfield, Intermediate Accounting: IFRS, Volume 1. USA: John Wiley \& Sons, 2010.

[6] K. C. Loudon and J. P. Loudon, Managament Information System Managing The Digital Firm, 13th Editi. Pearson Prentice Hall, 2016.

[7] G. H. Bodnar and W. S. Hoopwood, Accounting Information Systems. USA: Pearson Education Limited, 2014.

[8] N. Sajadi, M. Dastgir, and H. H. Najed, "Evaluation of The The Effectiveness Of Accounting Information Systems," Int. J. Inf. Sci. Technol., vol. 6, no. 2, 2008.

[9] J. W. Wilkinson, Accounting Information System: essential concepts and applications. USA: John Wiley \& Sons Inc, 1989.

[10] M. W. Hamdan, "The Impact Of Accounting Information System Development Life Cycle on its effectiveness And Critical Success Factors," Eur. Sci. J., vol. 8, no. 6, 2005.

[11] M. Eppler, Managing Information Quality. Springer Berlin-Heidelberg Germany, 2013.

[12] A. Cabrera, E. Cabrera, and S. Barajas, "The Key Role of Organizational Culture in a MultiSystem View of Technology-Driven Change,” Int. J. Inf. Manage., vol. 21, pp. 245-261, 2001, doi: 10.1016/S0268-4012(01)00013-5.

[13] E. H. Schein, Organizational Culture and Leadership. San Francisco: Josey-Bass Publishers, 2014.

[14] S. P. Robbins and T. A. Judge, Organizational Behavior, Edition 15. New Jersey: Pearson Education, 2013.

[15] N. Chatab, Profil Budaya Organisasi. Bandung: Penerbit Alfabeta, 2007.

[16] Supriyati and D. M. Rizky, "Model Perancangan Sistem Informasi Akuntansi Budidaya Perikanan Berbasis SAK EMKM dan Android," @is Best Account. Inf. Syst. Inf. Technol. Bus. Enterp., vol. 3, no. 2, 2018.

[17] R. Mc. Leod and G. P. Schell, Management Information Systems, 10th ed. New Jersey: Pearson Education, 2007.

[18] W. H. De Lone and E. R. McLean, "Information Systems Success: The Quest for the Dependent Variable,” Inf. Syst. Res., pp. 60-95, 2010.

[19] M. B. Romney and P. J. Steinbart, Accounting Information Systems. USA: Pearson Education, 2015.

[20] M. Salehi, "A study of the barriers of implementation of accounting information system: Case of listed companies in Tehran Stock Exchange," J. Econ. Behav. Stud., vol. 2, no. 2, pp. 76-85, 2011.

[21] A. I. Nicolaus, "A contingency model of perceived effectiveness in accounting information systems: Organizational coordination and control effects," Nicolaou Int. J. Account. Inf. Syst., vol. 1, no. 2, pp. 91-105, 2000.

[22] Sugiyono, Metode Penelitian Pendidikan Kuantitatif, Kualitatif, Dan R\&D. Bandung: Alfabeta, 2017.

[23] I. Ghozali, Aplikasi Analisis Multivariate Dengan Program Ibm Spss 20. Semarang: Badan Penerbit Universitas Diponegoro, 2013.

[24] J. E. J. Hair and A. Et, A Primer on Partial Least Squares Structural Equation Modeling (PLSSEM). California: SAGE Publications Inc., 2014. 
[25] L. Puspitawati, "The Analysis of Effectiveness Measurement In Accounting Information Systems Through Competence Factor Of Information System User-Research on Higher Education in Bandung," IJABER, vol. 14, no. 2, pp. 815-841, 2016.

[26] L. Puspitawati, A. Susanto, S. Poulus, and J. Suprijadi, "The critical success factors of the business strategy in the effectiveness of Management Accounting Information System evidence in Indonesia," J. Eng. Appl. Sci., vol. 13, no. 15, 2018. 